Jurnal Homepage: http://journal2.um.ac.id/index.php/jaa

(p-ISSN: 2087-9695; e-ISSN: 2580-1015)

\title{
Pengaruh karakteristik perusahaan terhadap tax avoidance serta dampaknya pada nilai perusahaan
}

\author{
Yosef Rago Andalan Nusa Putra ${ }^{* 1}$, Amir Indrabudiman ${ }^{1}$, Sugeng Riyadi ${ }^{1}$, Wuri Septi Handayani ${ }^{1}$ \\ ${ }^{1}$ Pascasarjana Universitas Budi Luhur,Jl. Ciledug Raya No. 99, Kota Jakarta Selatan, Indonesia
}

Diterima: Juni 2019
Direvisi: November 2019
Disetujui: Januari 2020
Koresponding:
Yosef Rago Andalan Nusa
Putra
alanrago284@gmail.com
DOI:
http://dx.doi.org/10.17977/
um004v7i12020p57

um004v7i12020p57

\begin{abstract}
The purpose of this study was to determine the effect of company charateristics on tax avoidance and it's effect on firm value. Sampling uses a purposive sampling method. The sample consisted of 19 agricultural sector companies listed on the Indonesia Stock Exchange in 2013-2017. The hypothesis is tested using partial least square software. The results showed profitability has a significant effect on tax avoidance, leverage doesn't have a significant effect on tax avoidance, firm size doesn't have a significant effect on tax avoidance, profitability has a significant effect on firm value, leverage doesn't have a significant effect on firm value, firm size has an influence on firm value. Tax avoidance has a significant effect on firm value, tax avoidance isn't able to mediate the effect of profitability on firm value, tax avoidance isn't able to mediate the effect of leverage on firm value, tax avoidance is able to mediate firm size on firm value. Keywords: company characteristics, tax avoidance, firm value
\end{abstract}

\begin{abstract}
Abstrak
Tujuan penelitian ini untuk mengetahui pengaruh karakteristik perusahaan terhadap penghindaran pajak serta dampaknya terhadap nilai perusahaan. Penarikan sampel menggunakan metode purposive sampling. Sampel terdiri atas 19 perusahaan sektor pertanian yang terdaftar di Bursa Efek Indonesia tahun 2013-2017. Hipotesis diuji menggunakan software partial least square. Hasil penelitian menunjukkan profitabilitas memiliki pengaruh yang signifikan pada tax avoidance. Leverage dan ukuran perusahaan tidak memiliki pengaruh yang signifikan pada tax avoidance. Profitabilitas dan ukuran perusahaan memiliki pengaruh yang signifikan pada nilai perusahaan. Leverage tidak memiliki pengaruh yang signifikan pada nilai perusahaan. Hasil penelitian juga menunjukkan bahwa tax avoidance berpengaruh signifikan terhadap nilai perusahaan, tetapi tidak mampu memediasi pengaruh profitabilitas dan leverage terhadap nilai perusahaan. Sebaliknya, tax avoidance mampu memediasi ukuran perusahaan terhadap nilai perusahaan.

Kata Kunci: karakteristik perusahaan, penghindaran pajak, nilai perusahaan
\end{abstract}

\section{PENDAHULUAN}

Konsep pembangunan Negara tidak terlepas dari sektor perpajakan. Pajak sebagai sumber pendapatan negara terbesar dan digunakan untuk pembangunan negara seperti pembangun infrastruktur, peningkatan pendidikan, penguatan ketahanan dan keamanan Negara, serta pembangunan daerah. Kenyataannya terjadi penurunan tax ratio yang menggambarkan penurunan persentase penerimaan pajak terhadap Produk Domestik Bruto (PDB). Tax ratio merupakan ukuran penilaian kesanggupan pemerintah dalam memungut pajak. Tabel 1 di bawah ini menggambarkan pertumbuhan tax ratio di Indonesia tahun 2013-2017.

Berdasarkan tabel 1, penurunan tax ratio dimulai tahun 2014 hingga 2016 dan meningkat kembali di tahun 2017. Peningkatan atau penurunan tax ratio adalah dampak dari kuat atau lemahnya sistem perpajakan yang ada di suatu negara. Penurunan tax ratio disebabkan karena banyaknya kasus penghindaran pajak, terutama pada perusahaan sektor pertanian.

Permasalahan besar yang dihadapi Indonesia dan negara lain dalam hal perpajakan yaitu rendahnya tingkat kepatuhan pajak dan kebocoran penerimaan pajak karena tingginya praktik penghindaran pajak. Penghindaran pajak adalah adalah langkah-langkah yang dilakukan oleh seseorang untuk menghindari pajak dengan cara-cara yang legal (Kemenkeu.go.id). Kessler, (2004) menyimpulkan tax avoidance sebagai upaya yang dilakukan wajib pajak untuk meminimalkan pajak dengan cara yang bertentangan dengan maksud dan tujuan dari ketentuan peraturan perundang-undangan. 
Tabel 1. Tax Ratio Indonesia

\begin{tabular}{cccccc}
\hline Tahun & $\mathbf{2 0 1 3}$ & $\mathbf{2 0 1 4}$ & $\mathbf{2 0 1 5}$ & $\mathbf{2 0 1 6}$ & $\mathbf{2 0 1 7}$ \\
\hline Tax Ratio (\%) & 11.9 & 11.4 & 10.7 & 10.3 & 10.9 \\
Sumber: www.kemenkeu.go.id & & &
\end{tabular}

Tabel 2. Tabel Kronologis Pemilihan Sampel

\begin{tabular}{clc}
\hline No & \multicolumn{1}{c}{ Kriteria } & Jumlah \\
\hline 1 & $\begin{array}{l}\text { Perusahaan sektor pertanian yang terdaftar di BEI pada periode 2013- } \\
2017\end{array}$ & 21 \\
2 & $\begin{array}{l}\text { Perusahaan sektor pertanian yang tidak menerbitkan laporan } \\
\text { keuangan beserta laporan auditor independen pada akhir tahun buku } \\
\text { per 31 Desember }\end{array}$ & $(2)$ \\
\hline \multicolumn{2}{c}{ Jumlah Sampel } & 19 \\
\hline
\end{tabular}

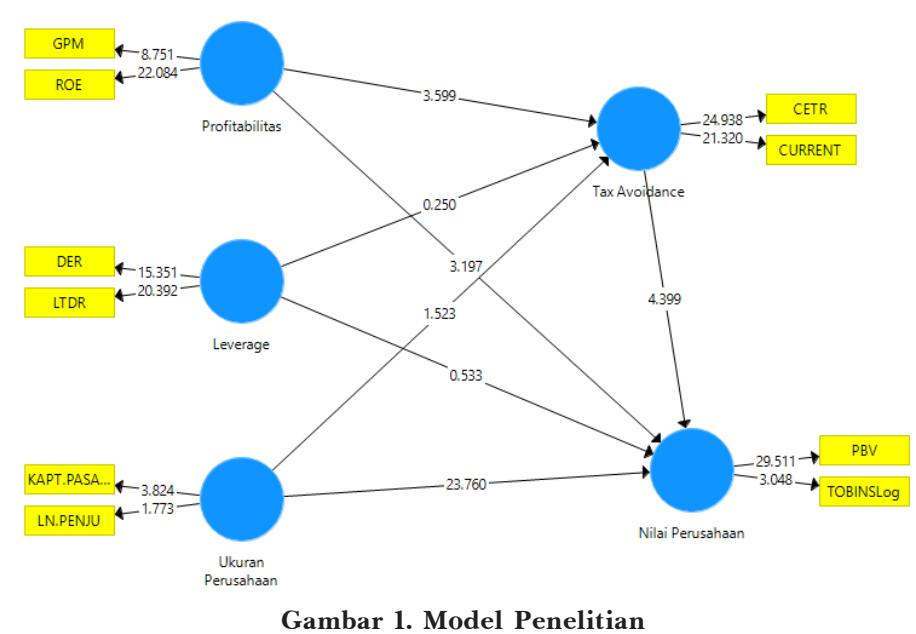

Dampak dari kegiatan penghindaran pajak yang dilakukan perusahaan yaitu penurunan harga saham, terutama pada sektor pertanian. Pergerakan harga saham sektor pertanian pada tahun 2013 saat penutupan adalah Rp 2.008.950. Angka ini mengalami penurunan yang signifikan di tahun 2017 dengan harga penutupan $\mathrm{Rp}$ 1.864.250. Terdapat beberapa faktor yang berimplikasi pada firm value yang tercermin dalam karakteristik perusahaan. Kegiatan penghindaran pajak dan firm value dapat dipengaruhi oleh profitabilitas, leverage, dan ukuran perusahaan (Ridho, 2016; Putri, 2017; Zaimah, 2013; Nadya, 2017; Muhamad, 2016; Sutardjo, 2017).

Tujuan dari riset ini adalah mengkaji pengaruh karakteristik perusahaan terhadap penghindaran pajak dan dampaknya pada nilai perusahaan. Sampel penelitian merupakan faktor disimilaritas dengan penelitian terdahulu. Sampel yang digunakan adalah perusahaan di sektor pertanian yang terdaftar di Bursa Efek Indonesia (BEI) tahun 2013-2017. Selain itu, penelitian ini menggunakan penghindaran pajak sebagai faktor mediasi (intervening) yang tidak digunakan pada penelitian sebelumnya.

\section{METODE}

\section{Populasi dan Sampel}

Populasi dari penelitian ini adalah 21 perusahaan di sektor pertanian yang terdaftar di BEI. Sektor pertanian dipilih karena analisis perkembangan industri tahun 2017 menunjukkan sektor pertanian mengalami penurunan PDB pada triwulan IV 2016 dengan persentase 5.53 dan pada Triwulan IV 2017 menjadi 2.24. Selain itu, terdapat banyak kasus penghindaran pajak yang umumnya dilakukan perusahaan pertanian. Metode penarikan sampel yaitu purposive sampling atau sampel bertujuan.

\section{Teknik Pengumpulan Data}

Pengumpulan data dalam penelitian ini dilakukan melalui studi dokumentasi. Untuk menjawab hipotesis penelitian, data diolah menggunakan software pemodelan persamaan struktural dengan penafsiran PLS.

\section{Model Penelitian}

Model penelitian dalam penelitian dapat dilihat pada gambar 1. 
Tabel 3. Uji Validitas

\begin{tabular}{|c|c|c|c|c|}
\hline Dimensi & Loadings Factor & AVE & Kriteria & Keterangan \\
\hline \multicolumn{5}{|c|}{ PROFITABILITAS $\left(\mathrm{X}_{1}\right)$} \\
\hline GPM & 0,710 & \multirow{2}{*}{0,639} & 0.500 & Valid \\
\hline ROE & 0,879 & & 0.500 & Valid \\
\hline \multicolumn{5}{|c|}{ LEVERAGE $\left(\mathrm{X}_{2}\right)$} \\
\hline DER & 0,900 & \multirow{2}{*}{0,846} & 0.500 & Valid \\
\hline LTDR & 0,939 & & 0.500 & Valid \\
\hline \multicolumn{5}{|c|}{ UKURAN PERUSAHAN $\left(\mathbf{X}_{3}\right)$} \\
\hline KAPT.PASAR & 0,667 & \multirow{2}{*}{0,735} & 0.500 & Valid \\
\hline LN.PENJUALAN & 0,869 & & 0.500 & Valid \\
\hline \multicolumn{5}{|c|}{ TAX A VOIDANCE (Y) } \\
\hline CETR & 0,819 & \multirow{2}{*}{0,724} & 0.500 & Valid \\
\hline CURRENT & 0,881 & & 0.500 & Valid \\
\hline \multicolumn{5}{|c|}{ NILAI PERUSAHAAN (Z) } \\
\hline PBV & 0,994 & \multirow{2}{*}{0,734} & 0.500 & Valid \\
\hline TOBINS'Q & 0,692 & & 0.500 & Valid \\
\hline
\end{tabular}

Tabel 4. Uji Reliabilitas

\begin{tabular}{cccccc}
\hline Variabel & Cronbachs Alpha & rho_A & Composite Reliability & Kriteria & Keterangan \\
\hline Profitabilitas & 0,748 & 0,891 & 0,777 & 0,700 & Reliabel \\
Leverage & 0,821 & 0,853 & 0,917 & 0,700 & Reliabel \\
Ukuran Perusahaan & 0,748 & 0,882 & 0,747 & 0,700 & Reliabel \\
Tax Avoidance & 0,721 & 0,836 & 0,839 & 0,700 & Reliabel \\
Nilai Perusahaan & 0,758 & 3,551 & 0,842 & 0,700 & Reliabel \\
\hline
\end{tabular}

Tabel 5. Rekapitulasi Kecocokan model

\begin{tabular}{cccc}
\hline Indikator & Olahan & Kriteria & Keterangan \\
\hline SRMR & 0,043 & $<0,08^{\mathrm{a}}$ & Lolos uji \\
NFI & 0,957 & $>0,90^{\mathrm{b}}$ & Lolos uji \\
rms Theta & 0,022 & $<0,12^{\mathrm{a}}$ & Lolos uji \\
\hline
\end{tabular}

\section{HASIL DAN PEMBAHASAN}

\section{Uji Validitas}

Tabel 3 menunjukkan bahwa nilai semua indikator lebih besar dari kriteria 0.5. Artinya, semua indikator dalam dimensi dan variabel memiliki validitas yang baik.

\section{Uji Reliabilitas}

Tabel 4 menunjukkan bahwa semua uji reliabilitas diatas kriteria 0.7 untuk semua variabel. Dengan demikian, seluruh variabel (profitabilitas (X1), leverage (X2), ukuran perusahaan (X3), tax avoidance $(\mathrm{Y})$, nilai perusahaan $(\mathrm{Z})$ ) konsisten dapat dipercaya untuk digunakan dalam penelitian.

\section{Model Fit}

Tabel 5 menunjukkan bahwa ketiga indikator (SRMR, NFI, dan rms Theta) di atas kriteria. Artinya, model fit atau data cocok dengan model.

\section{Uji Hipotesis}

Tabel 6 menunjukkan bahwa seluruh nilai t-statistik dari indikator ke variabel $>1.96$ dan seluruh nilai p-value dari indikator ke variabel $<0,05$. Artinya, seluruh nilai weights serta loading factors adalah relevan. Sebaliknya, t-statistik dan p-value dari variabel ke variabel ada 3 (tiga) yang tidak signifikan, yaitu pengaruh leverage terhadap penghindaran pajak, pengaruh leverage terhadap firm value dan pengaruh ukuran perusahaan terhadap penghindaran pajak. Secara mediasi, penghindaran pajak tidak dapat memediasi hubungan profitabilitas dan leverage pada firm value, namun dapat memediasi hubungan antara ukuran perusahaan pada firm value. 
Tabel 6. Uji Hipotesis

\begin{tabular}{|c|c|c|c|}
\hline Jalur & T Statistik $(>1.96)$ & P Values $(<0.05)$ & Keterangan \\
\hline \multicolumn{4}{|c|}{ Dari Indikator ke Variabel } \\
\hline GPM & 8.751 & 0.002 & Signifikan \\
\hline ROE & 22.084 & 0.000 & Signifikan \\
\hline DER & 15.351 & 0.000 & Signifikan \\
\hline KAPT.PSR & 3.824 & 0.016 & Signifikan \\
\hline Ln.PENJ & 1.773 & 0.017 & Signifikan \\
\hline CETR & 24.938 & 0.000 & Signifikan \\
\hline CURRENT & 21.320 & 0.000 & Signifikan \\
\hline PBV & 29.511 & 0.000 & Signifikan \\
\hline TOBINS'Q Log & 3.048 & 0.028 & Signifikan \\
\hline \multicolumn{4}{|c|}{ Dari Variabel ke Variabel } \\
\hline Profitabilitas -> Tax Avoidance & 3.599 & 0.018 & Signifikan \\
\hline Profitabilitas -> Nilai Perusahaan & 3.197 & 0.025 & Signifikan \\
\hline Leverage -> Tax Avoidance & 0.250 & 0.409 & Tidak Signifikan \\
\hline Leverage -> Nilai Perusahaan & 0.533 & 0.316 & Tidak Signifikan \\
\hline Ukuran Perusahaan -> Tax Avoidance & 1.523 & 0.113 & Tidak Signifikan \\
\hline Ukuran Perusahaan $\rightarrow>$ Nilai Perusahaan & 23.760 & 0.000 & Signifikan \\
\hline Tax Avoidance -> Nilai Perusahaan & 4.399 & 0.011 & Signifikan \\
\hline \multicolumn{4}{|c|}{ Mediasi } \\
\hline Variabel & Direct & lindirect & Total effect \\
\hline Profitabilitas $>$ penghindaran pajak $>$ firm value & -0.263 & -0.012 & -0.275 \\
\hline Leverage $>$ penghindaran pajak $>$ firm value & 0.164 & -0.002 & 0.162 \\
\hline Ukuran $>$ penghindaran pajak > firm value & -0.275 & 0.014 & -0.262 \\
\hline
\end{tabular}

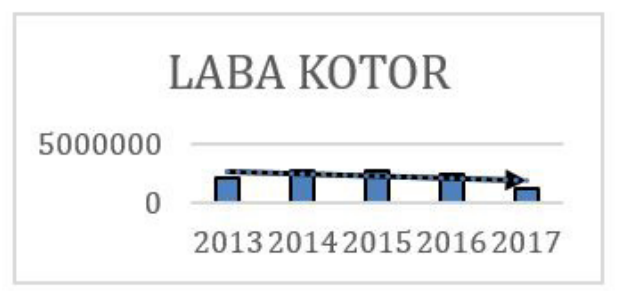

Gambar 2. Laba Kotor Perusahaan

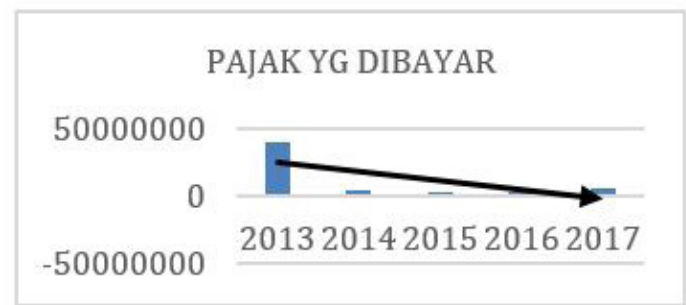

Gambar 3. Penurunan Jumlah Pajak yang Dibayar
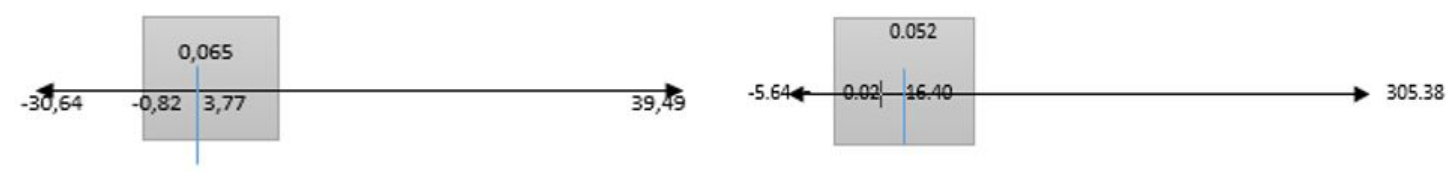

Gambar 4. Garis Trend Leverage dan Tax Avoidance
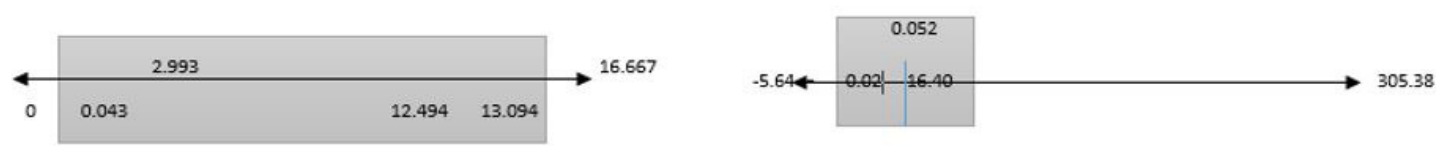

Gambar 5. Garis Trend Ukuran Perusahaan dan Tax Avoidance 


\section{Pengaruh Profitabilitas terhadap Tax Avoidance}

Hasil uji hipotesis menunjukkan rasio laba atau profitabilitas memiliki dampak yang signifikan pada kegiatan penghindaran pajak. Peningkatan nilai profitabilitas menunjukkan peningkatan tax avoidance, sebaliknya penurunan profitabilitas menunjukkan penurunan tax avoidance. Profitabilitas dalam penelitian ini diproksikan dengan Gross Profit Margin (GPM), sedangkan tax avoidance diproksikan dengan Cash Effective Tax Rate (CETR). Margin laba kotor (GPM) adalah jumlah perbandingan laba kotor terhadap penjualan.

Gambar 2 dan 3 menunjukkan jumlah laba kotor yang semakin menurun. Hal ini menjadi penyebab profitabilitas mengalami penurunan dan membuat tax avoidance menurun. Dalam hal ini, pembayaran pajak menurun. Perusahaan dengan laba yang rendah diindikasikan melakukan praktik tax avoidance. Penghematan jumlah beban pajak yang menyebabkan peningkatan profit adalah strategi perusahaan dalam melakukan tindakan tax avoidance. Hasil uji hipotesis konsisten dengan Nengzih (2018) yang membuktikan penghindaran pajak dipengaruhi oleh profitabilitas.

\section{Pengaruh Leverage terhadap Tax Avoidance}

Hasil analisis dan pengujian hipotesis menunjukkan rasio utang atau leverage tidak memiliki dampak atau pengaruh pada penghindaran pajak. Hal ini memiliki makna besar kecilnya leverage tidak memengaruhi penghindaran pajak. Kondisi ini dapat dibuktikan pada gambar 4 .

Gambar 4 menjelaskan hubungan kedua variabel. Kedua variabel memiliki hubungan yang tidak berpengaruh positif karena arah pergerakannya sama-sama jauh antara nilai minimum dan nilai maximum. Variabel leverage hanya bergerak di kisaran 0.065 , sedangkan nilai tertinggi pada variabel leverage adalah 39.49. Hal ini juga berlaku pada variabel tax avoidance. Tax avoidance hanya bergerak di kisaran 0.052, sedangkan nilai tertinggi variabel tax avoidance adalah 305.38. Dengan demikian, kedua variabel tidak berpengaruh dengan arah positif.

Leverage diproksikan dengan indikator DER, sedangkan tax avoidance diproksikan dengan CETR. Semakin tinggi utang perusahaan, jumlah pajak yang dibayar semakin menurun. Biaya bunga yang tinggi dari utang menyebabkan berkurangnya jumlah pembayaran pajak oleh pihak perusahaan. Kondisi ini menunjukkan tidak berpengaruhnya leverage terhadap tax avoidance. Penelitian ini konsisten dengan penelitian Pasca dwi (2017) yang menunjukkan leverage tidak berdampak pada penghindaran pajak. Namun, tidak sesuai dengan penelitian Putri (2017) yang menunjukkan leverage memiliki dampak signifikan pada tax avoidance.

\section{Pengaruh Ukuran Perusahaan terhadap Tax Avoidance}

Analisis dan pengujian hipotesis menunjukkan firm size tidak memiliki dampak pada praktik penghindaran pajak. Artinya, peningkatan atau penurunan firm size tidak memengaruhi penghindaran pajak. Kondisi ini dapat dibuktikan pada gambar 5 .

Gambar 5 menjelaskan hubungan kedua variabel. Kedua variabel memiliki hubungan yang tidak berpengaruh dengan arah negatif. Pada variabel ukuran perusahaan arah pergerakan variabel penjualan menyebar secara merata, sedangkan variabel penjualan hanya bergerak di daerah minimum. Dengan demikian, kedua variabel tidak berpengaruh dengan arah negatif.

Hasil penelitian yang menunjukkan ukuran perusahaan tidak berpengaruh terhadap tax avoidance menjabarkan bahwa perusahaan besar mendapat perhatian yang lebih besar dari pemerintah terkait dengan laba yang diperoleh. Dengan kata lain, perusahaan besar menarik perhatian fiskus untuk dikenai pajak sesuai aturan yang berlaku. Hal ini tidak berlaku karena membayar pajak merupakan kewajiban perusahaan. Perusahaan besar atau kecil akan dikejar fiskus apabila melanggar peraturan perpajakan. Penelitian ini sesuai dengan Turyatini (2017), tax avoidance dipengaruhi oleh ukuran perusahaan.

\section{Pengaruh Profitabilitas terhadap Nilai Perusahaan}

Analisis dan pengujian hipotesis menunjukkan rasio laba atau profitabilitas mempunyai dampak pada firm value. Apabila laba perusahaan mengalami penurunan, maka nilai perusahaan mengalami peningkatan. Kondisi ini dapat dibuktikan pada gambar 6.

Rasio laba diproksikan dengan GPM, sedangkan nilai perusahaan direfleksikan dengan Tobins'q. Gambar 6 merupakan elemen dari GPM. Nilai GPM dipengaruhi oleh laba kotor. Penelitian ini menemukan bahwa tidak selamanya profitabilitas rendah berdampak pada nilai perusahaan yang rendah. Peningkatan nilai perusahaan dapat dilakukan pula melalui peningkatan jumlah saham yang beredar. Peningkatan jumlah saham yang beredar menyebabkan investor merasa yakin dengan fundamental perusahaan. Uji hipotesis konsisten dengan William (2016), Sutardjo (2017) yang menunjukkan profitabilitas memiliki dampak signifikan pada firm value. 

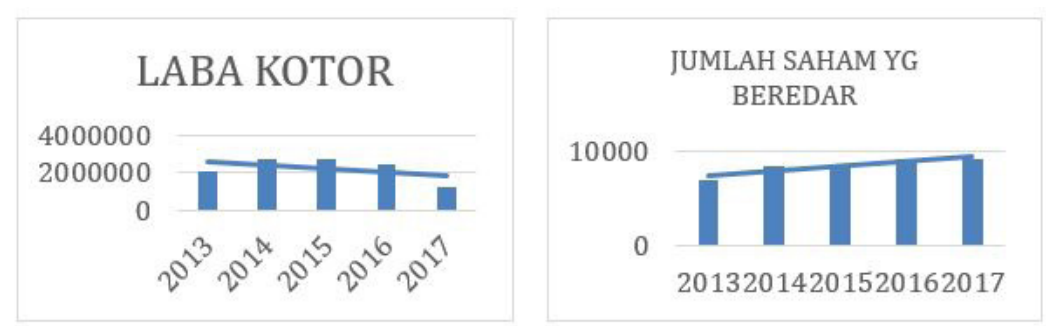

Gambar 6. Elemen Profitabilitas dan Nilai Perusahaan

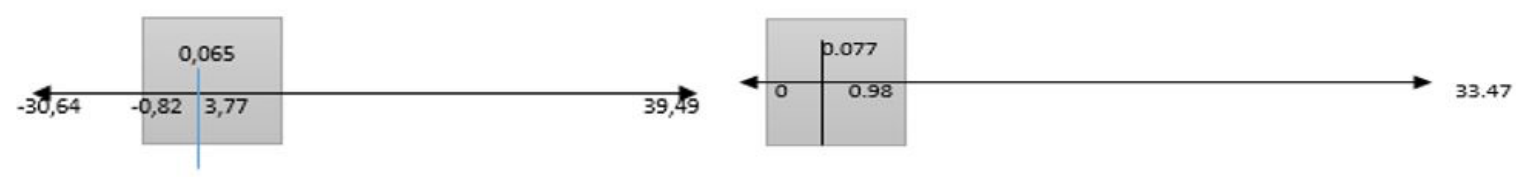

Gambar 7. Garis Trend Leverage dan Nilai Perusahaan

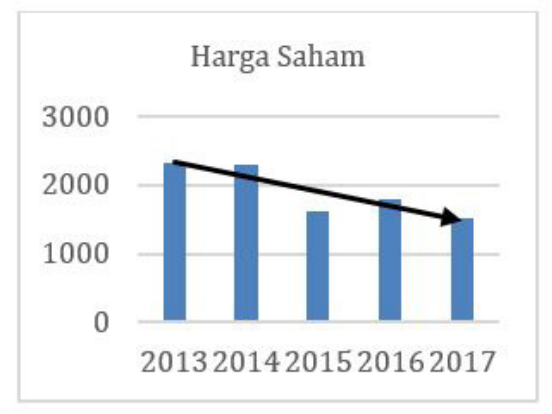

Gambar 8. Elemen Nilai Perusahaan
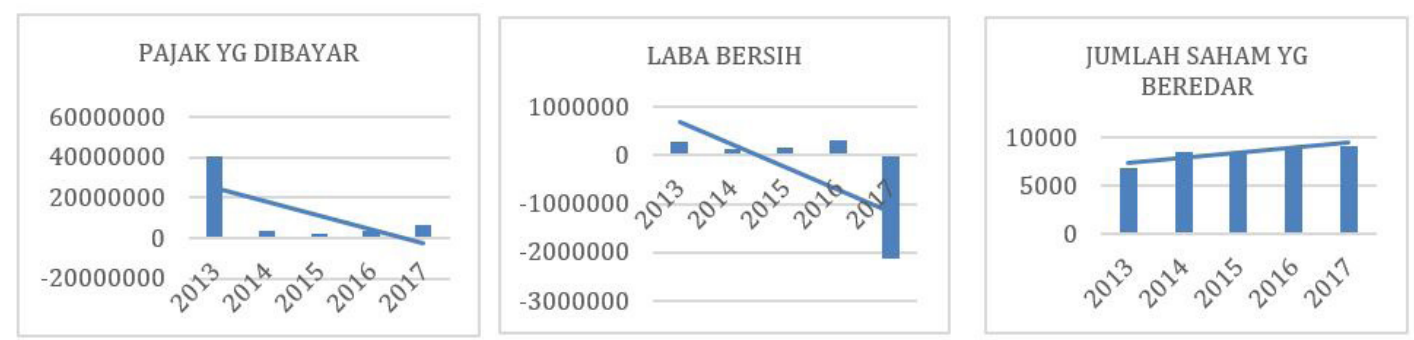

Gambar 9. Elemen Tax Avoidance dan Nilai Perusahaan
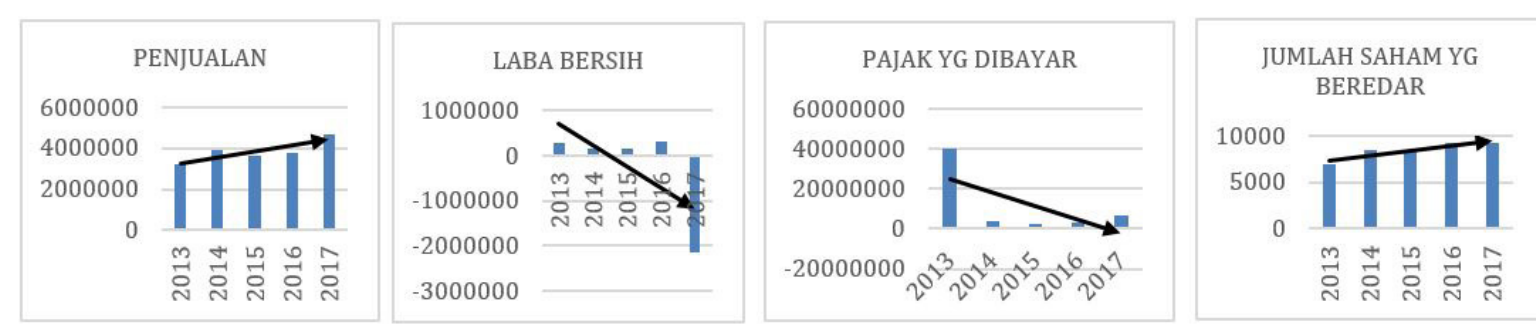

Gambar 10. Elemen Profitabilitas, Tax Avoidance, Nilai Perusahaan
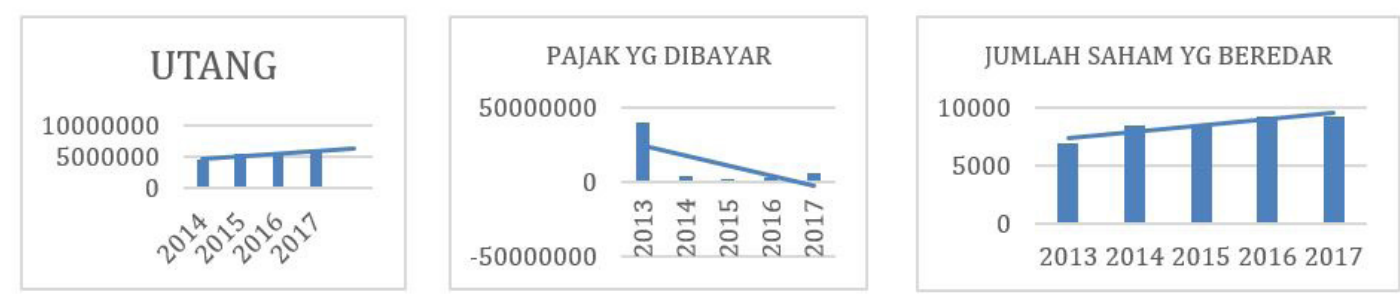

Gambar 11. Elemen Leverage, Tax Avoidance, Nilai Perusahaan 


\section{Pengaruh Leverage terhadap Nilai Perusahaan}

Analisis dan pengujian hipotesis menunjukkan rasio utang atau variabel leverage tidak memiliki dampak pada firm value. Kondisi ini dapat dibuktikan pada gambar 7.

Gambar 7 menjelaskan hubungan kedua variabel. Kedua variabel memiliki hubungan yang tidak berpengaruh positif karena arah pergerakannya sama-sama jauh antara nilai minimum dan nilai maximum. Variabel leverage hanya bergerak di kisaran 0.065 , sedangkan nilai tertinggi pada variabel leverage adalah 39.49. Hal ini juga berlaku pada variabel nilai perusahaan. Variabel nilai perusahaan hanya bergerak di kisaran 0.077, sedangkan nilai tertinggi variabel nilai perusahaan adalah 33.47. Dengan demikian, kedua variabel tidak berpengaruh dengan arah positif.

Dalam menjalankan usahanya, investor menggunakan modal sendiri dan modal eksternal (pinjaman). Dalam hal ini, utang tidak menjadi patokan utama perusahaan. Faktor lain yang menjadi acuan investor dalam melakukan investasi adalah tingkat laba suatu perusahaan. Laba yang tinggi menunjukkan kinerja perusahaan semakin baik. Hasil uji hipotesis tidak sejalan dengan Ming cheng (2016), Muhammad (2016), Obradovich (2013) yang menjelaskan leverage berdampak pada firm value.

\section{Pengaruh Ukuran Perusahaan terhadap Nilai Perusahaan}

Analisis dan pengujian hipotesis menunjukkan firm size memiliki dampak signifikan pada firm value. Yang artinya besar kecilnya firm size atau ukuran perusahaan memengaruhi firm value. Firm size diproksikan oleh total penjualan, sedangkan firm value diproksikan dengan PBV. Teori menunjukkan tingkat penjualan yang tinggi mencerminkan kondisi perusahaan dalam keadaan baik dan memeroleh laba, serta mendapat kepercayaan yang tinggi dari investor untuk melakukan investasi. Hasil penelitian ini berbeda dan tidak sesuai teori. Hasil analisis menunjukkan walaupun ukuran perusahaan meningkat, secara fundamental kondisi perusahaan buruk. Terbukti pada trend harga saham yang menurun. Trend harga saham dapat dibuktikan pada gambar 8.

Kondisi fundamental suatu perusahaan dikatakan baik, apabila harga sahamnya meningkat. Selain fundamental perusahaan, investor ingin menanamkan sahamnya pada perusahaan yang memiliki prospek yang baik, tidak tergantung dengan besar kecilnya perusahaan. Sebesar apapun perusahaan ketika terdengar isu atau rumor bahwa perusahaan tersebut sedang mengalami kerugian dan diambang kebangkrutan maka secara otomatis para investor tidak akan menanamkan modalnya pada perusahaan tersebut. Hal ini tentunya berdampak pada turunnya nilai saham pada perusahaan tersebut. Penelitian ini sesuai dengan Khumairoh (2016), Vince (2018), Nenggar (2005), Obradovich (2013), Sutardjo (2017) yang menunjukkan ukuran perusahaan berdampak pada firm value.

\section{Pengaruh Tax Avoidance terhadap Nilai Perusahaan}

Analisis dan pengujian hipotesis menunjukkan nilai perusahaan dipengaruhi oleh tax avoidance. Artinya, semakin meningkat penghindaran pajak, firm value menurun, dan sebaliknya. Kondisi ini dapat dibuktikan pada gambar 9.

Gambar 9 menunjukkan pajak yang dibayarkan oleh perusahaan menunjukkan arah yang menurun. Penurunan pajak yang dibayarkan disebabkan laba bersih perusahaan yang menurun. Untuk meningkatkan laba bersih, perusahaan meningkatkan penerbitan jumlah saham yang beredar. Hal ini selanjutnya berdampak pada nilai perusahaan yang meningkat. Penelitian ini sesuai penelitian Rifki (2017), Lisa Simeone (2012) yang menunjukkan nilai perusahaan dipengaruhi tax avoidance.

\section{Pengaruh Profitabilitas terhadap Nilai Perusahaan dengan Tax Avoidance sebagai}

\section{Variabel Intervening}

Analisis dan pengujian hipotesis menunjukkan tax avoidance tidak mampu memediasi dampak profitabilitas pada firm value. Investor tidak hanya melihat besar kecilnya tax avoidance dalam melakukan investasi, namun lebih tertuju pada kinerja perusahaan memeroleh laba. Apabila perusahaan mengalami peningkatan laba, kemampuan perusahaan membayar dividen juga meningkat. Kondisi ini juga memiliki pengaruh pada kenaikan firm value. Di sisi lain, laba perusahaan mengalami penurunan walaupun terjadi peningkatan penjualan. Penurunan laba disebabkan karena biaya yang tinggi. Laba perusahaan yang menurun berdampak pada pembayaran pajak perusahaan yang kecil. Kondisi profitabilitas, tax avoidance, dan nilai perusahaan tercermin pada gambar 10.

Gambar 10 menunjukkan nilai penjualan perusahaan meningkat. Di sisi lain, laba perusahaan mengalami penurunan walaupun terjadi peningkatan penjualan. Penurunan laba disebabkan karena biaya yang tinggi. Laba perusahaan yang menurun berdampak pada pembayaran pajak perusahaan yang kecil. Untuk meningkatkan citra perusahaan, yang disebabkan profitabilitas yang rendah, perusahaan meningkatkan jumlah saham yang beredar. Peningkatan jumlah saham yang beredar berdampak pada nilai perusahaan yang meningkat. 

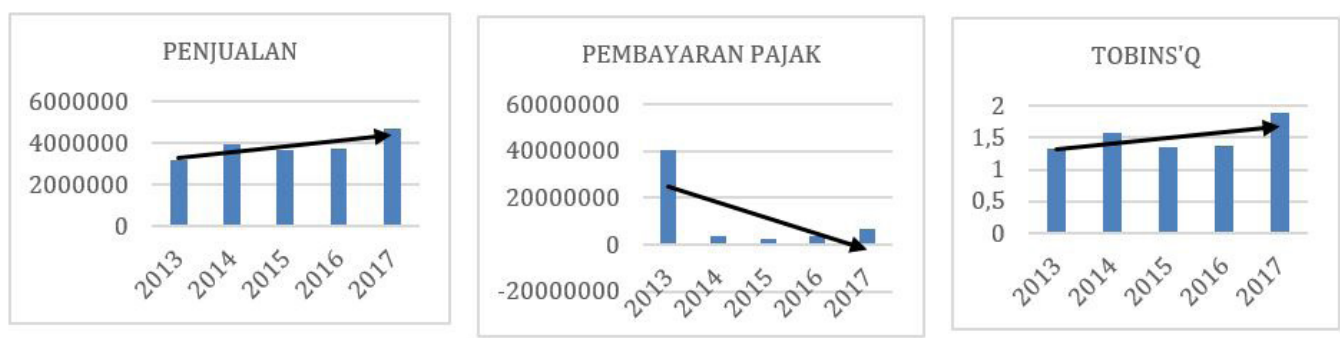

Gambar 12. Elemen Ukuran Perusahaan, Tax Avoidance, Nilai Perusahaan

\section{Pengaruh Leverage terhadap Nilai Perusahaan dengan Tax Avoidance sebagai Variabel Intervening}

Analisis dan pengujian hipotesis menunjukkan tax avoidance tidak dapat memediasi dampak leverage pada firm value. Dalam melakukan investasi investor tidak hanya melihat pada kondisi praktik penghindaran pajak, namun lebih pada kemampuan perusahaan mengelola utang. Leverage penelitian ini direfleksikan oleh Debt to Equity Ratio (DER). Kondisi tax avoidance tidak mampu memediasi pengaruh leverage terhadap nilai perusahaan tercermin pada gambar 11 .

Gambar 11 menunjukkan tingkat utang perusahaan meningkat. Semakin tinggi jumlah pendanaan yang berasal dari utang, maka semakin tinggi juga biaya bunga yang timbul dari utang tersebut. Biaya bunga yang tinggi akan berdampak pada berkurangnya beban pajak perusahaan. Semakin tinggi leverage, maka tindakan penghindaran pajak akan semakin tinggi. Utang yang menyebabkan munculnya beban bunga dapat menjadi pengurang laba kena pajak. Untuk meningkatkan citra perusahaan di mata investor, perusahaan meningkatkan penerbitan jumlah saham yang beredar. Di sisi lain, peningkatan hutang dapat dianggap sebagai peningkatan kemampuan perusahaan untuk memberikan pengembalian lebih kepada investor tanpa harus mengurangi proporsi kepemilikan. Dengan demikian, nilai perusahaan turut meningkat.

\section{Pengaruh Ukuran Perusahaan terhadap Nilai Perusahaan dengan Tax Avoidance sebagai Variabel Intervening}

Analisis dan pengujian hipotesis menunjukkan tax avoidance dapat memediasi dampak ukuran perusahaan pada firm value. Ukuran adalah icon yang dikaitkan dengan pelaporan keuangan. Kondisi variabel ukuran perusahaan, tax avoidance, dan nilai perusahaan sektor pertanian yang terdaftar di BEI tahun 2013-2017 terlihat pada gambar 12.

Gambar 12 menunjukkan ukuran perusahaan dan nilai perusahaan mengalami peningkatan, sedangkan tax avoidance mengalami penurunan dari tahun 2013-2017. Peningkatan tingkat penjualan, yang disebabkan oleh pembayaran pajak yang rendah, berdampak pada nilai perusahaan yang meningkat. Pembayaran pajak yang menurun berdampak pada harga saham yang meningkat.

Semakin besar suatu perusahaan menyebabkan nilai perusahaan meningkat karena peningkatan jumlah saham yang beredar. Untuk meningkatkan nilai perusahaan, perusahaan melakukan penghindaran pajak. Tax avoidance merupakan upaya yang dilakukan wajib pajak untuk meminimalkan pajak dengan cara yang bertentangan dengan maksud dan tujuan dari ketentuan peraturan perundang-undangan.

Perusahaan dengan ukuran yang besar menunjukkan kestabilan dan kemampuan perusahaan untuk melakukan aktivitas ekonominya. Perusahaan yang besar tentu memiliki sumber daya manusia yang ahli dalam mengelola beban pajaknya. Penghindaran pajak yang dilakukan manajemen yaitu dengan cara menghemat beban pajak sehingga dapat meningkatkan laba perusahaan. Laba perusahaan yang meningkat mendapatkan reaksi positif dari investor. Hal ini selanjutnya berdampak pada nilai perusahaan yang meningkat.

\section{SIMPULAN}

GPM berpengaruh terhadap penghindaran pajak, DER tidak berpengaruh pada penghindaran pajak. Penjualan tidak berpengaruh pada penghindaran pajak. GPM berpengaruh pada nilai perusahaan. DER tidak berpengaruh pada nilai perusahaan. Penjualan berpengaruh pada nilai perusahaan. CETR berpengaruh pada nilai perusahaan. Tax avoidance tidak dapat memediasi dampak profitabilitas pada nilai perusahaan. Tax avoidance tidak dapat memediasi dampak leverage terhadap nilai perusahaan. Tax avoidance dapat memediasi pengaruh ukuran perusahaan terhadap nilai perusahaan. Peneliti selanjutnya diharapkan untuk mengembangkan variabel-variabel lain 
yang mungkin ikut memengaruhi tax avoidance. Adapun faktor-faktor lain yang memengaruhi tax avoidance yang berdampak pada nilai perusahaan adalah good corporate governance dan pertumbuhan perusahaan. Selain itu, penggunaan sampel yang lebih luas dan penambahan periode pengamatan juga disarankan agar hasil penelitian lebih representatif.

\section{DAFTAR RUJUKAN}

Adenugba, I. K. (2016). Financial leverage and firms value: A study of selected firms in Nigeria. European Journal of Research and Reflection in Management Sciences, https://www. idpublications.org/...Full-Paper-Financial-L...

Bringham, H. (2001). Manajemen keuangan Edisi 8. Jakarta: Erlangga.

Christine. (2012). Tax avoidance and corporate capital structure. Journal of Finance and Accountancy, www.aabri.com/manuscripts/121289.pdf.

Ikatan Akuntan Indonesia. (2018). Modul Pelatihan Pajak Terapan Brevet AB Terpadu. Jakarta: Ikatan Akuntan Indonesia.

Jensen, M. (1976). Theory of the Firm: Managerial Behavior, Agency Costs and Ownership Structure. Journal of Financial Economics, 3, https://www2.bc.edu/thomas-chemmanur/phdfincorp/ MF891\%20papers/Jensen\%20and\%20Meckling\%201976.pdf.

Jeongho, C. (2017). Study on corporate social responsibility (CSR) : focus on tax avoidance and financial ratio analysis. Research Assistant of Institute of Global Business Research, Hankuk University of Foreign Studies, www.mdpi.com/2071-1050/9/10/1710/pdf.

Kesler, J. (2004). Tax avoidance and purpose section. british tax review, www.ortax.org/ortax/?mod= issue\&page $=$ show\&id $=36 \&$ hlm $=2$.

Khumairoh. (2016). Pengaruh Leverage, Profitabilitas, Dan Ukuran Perusahaan Terhadap Nilai Perusahaan. Syariah Paper Accounting FEB UMS, https://publikasiilmiah.ums.ac.id/bitstream/ handle/11617/7347/7\%20-\%20Khumairoh.pdf? sequence $=1$.

Ming, C. Z. (2011). The effect of leverage on firm value and how the firm financial quality influence on this effect. World Journal of Management, https:/www.researchgate.net/.../228843342_The_ Effect_of_Leverage_on_Firm_Valu.

Muhammad, A. (2016). Impact of financial leverage on value of firms: evidence from cement sector of pakistan. Research Journal of Finance and Accounting: http://citeseerx.ist.psu.edu/viewdoc/ download?doi=10.1.1.911.4388\&rep=rep1\&type=pdf.

Nadya, I. (2017). The effect of financial ratios on frim value in the food and beverage sector of the idx. Journal of Business and Management, 6(2), 2017: 214-226, journal.sbm.itb.ac.id/index.php/ jbm/article/download/.../112...

Nenggar. (2015). Analyzing The Effect Of Capital Structure And Firm Size On Firm Value (Case Study: Company That Listed In Lq-45 Index Period 2010-2014). Jurnal Berkala Ilmiah Efisiensi, download.portalgaruda.org/article.php?...ANALYZING\%20...

Nengzih. (2018). Determinant of corporate tax avoidance: survey on indonesia's public listed company. International Journal of Economics, Business and Management Research, ijebmr. com/uploads2018/IJEBMR_02_159.pdf.

Obradovich, J. (2013). The impact of corporate governance and financial leverage on the value of american firms. Liberty University, http://digitalcommons.liberty.edu/busi_fac_pubs/25.

Pasca D., Dedi, Tuti. (2017). Tax avoidance practices as a proof of agency theory and tax planning in indonesia stock exchange. Proceedings of International Conference on Innovation in Education, Science, and Culture (ICIESC-2017), https://iciesc.unimed.ac.id/wp-content/.../05/66.-Hal-474479-Pasca-Dwi-Putra.pdf.

Pratama, A. (2016). Company charateristic, corporate governance and aggresive tax avoidance practice: a study of indonesian companies. Buscompress, http://sibresearch.org/uploads/3/4/0/9/34097180/ riber_6-4_05b17-080_70-81.pdf. 
Pratama, Arie. (2018). Do related party transactions and tax avoidance affect firm value? buscompress. http://buscompress.com/uploads/3/4/9/8/34980536/riber_7-s1_sp_h17-089_106-116.pdf.

Putri, A. (2017). The influence of leverage and firm size to tax avoidance (case study on sub sector coal company listed in indonesia stock exchange period 2012-2016). Unikom, http://elib.unikom. ac.id/files/disk1/751/jbptunikompp-gdl-putrirahay-37546-1-unikom_p-e.pdf.

Ridho. (2016). Pengaruh ukuran perusahaan, leverage, profitabilitas, dan sales growth terhadap penghindaran pajak (tax avoidance) pada perusahaan manufaktur di bursa efek indonesia tahun 2010-2014. UIN JAKARTA, repository.uinjkt.ac.id/dspace/.../1/Muhammad\%20ridho\%20 $-\% 20 \mathrm{FEB} . p d f$.

Riefka. (2016). Pengaruh Karakteristik Perusahaan terhadap Penghindaran Pajak pada Perusahaan Manufaktur Di BEI. Jurnal Ilmu dan Riset Akuntansi, 5(2).

Sabrin, Buyung, Dedy, Sujono. (2016). The effect of profitability on firm value in manufacturing company at indonesia stock exchange. The International Journal Of Engineering And Science (IJES), www.theijes.com/papers/v5-i10/K0501081089.pdf.

Simeone, L. (2012). Do investors value tax avoidanceof income mobile firms?? The University of Texas at Austin, https://www.ssrn.com/abstract $=2102903$.

Sutardjo, Mahfud, Muklis, Andi. (2017). Determinants of profitability and firm value : evidence from indonesian banks. IRA-International Journal of Management \& Social Sciences, http://researchadvances.org/index.php/RAJMSS.

Turyatini. (2016). Analysis of tax avoidance determinant on the property and real estate companies. Jurnal Dinamika Akuntansi, http://journal.unnes.ac.id/nju/index.php/jda.

Vince, Azhari, Demond, Nita. (2018). The impact of institusional ownership and a firm's size on firm value : tax avoidance as a moderating variable. Global Academy of Training \& Research (GATR) Enterprise, https://papers.ssrn.com/abstract=3188527.

Vivi. (2017). Pengaruh kebijakan deviden, profitabilitas, leverage, dan size terhadap nilai perusahaan. UIN JAKARTA, repository.uinjkt.ac.id/dspace/bitstream/.../2/VIVI\%20FATIA\%20UTAMI-FEB. pdf.

William, J. M. (2016). Influence of Profitability to the Firm Value of Diversified Companies in the Philippines. Published by Sciedu Press, http://dx.doi.org/10.5430/afr.v5n2p149.

Zaimah. (2013). Avoiding tax: does firm size and profitability matter?. Proceedings of the 6th International Conference of the Asian Academy of Applied Business (AAAB)2013, http://www. ums.edu.my/fpep/files/ACC02_2013.pdf. 